Article

\title{
Novel Models of Streptococcus canis Colonization and Disease Reveal Modest Contributions of M-Like (SCM) Protein
}

\author{
Ingrid Cornax $^{1,+, \ddagger}$, Jacob Zulk ${ }^{2,+} \mathbb{D}$, Joshua Olson ${ }^{1}$, Marcus Fulde ${ }^{3}$, Victor Nizet ${ }^{1,4}$ and Kathryn A Patras ${ }^{2, * \mathbb{D}}$ \\ 1 Department of Pediatrics, UC San Diego, La Jolla, CA 92093, USA; icornax@its.jnj.com (I.C.); \\ jaolson@health.ucsd.edu (J.O.); vnizet@health.ucsd.edu (V.N.) \\ 2 Department of Molecular Virology and Microbiology, Baylor College of Medicine, 1 Baylor Plaza, Houston, \\ TX 77030, USA; jacob.zulk@bcm.edu \\ 3 Institute of Microbiology and Epizootics, Centre of Infection Medicine, Freie Universität Berlin, 14163 Berlin, \\ Germany; Marcus.Fulde@fu-berlin.de \\ 4 Skaggs School of Pharmacy and Pharmaceutical Sciences, UC San Diego, La Jolla, CA 92093, USA \\ * Correspondence: katy.patras@bcm.edu \\ + These authors contributed equally to this work. \\ $\ddagger$ Present address: Janssen Research \& Development, LLC, La Jolla, CA 92121, USA.
}

Citation: Cornax, I.; Zulk, J.; Olson, J.; Fulde, M.; Nizet, V.; Patras, K.A. Novel Models of Streptococcus canis Colonization and Disease Reveal Modest Contributions of M-Like (SCM) Protein. Microorganisms 2021, 9 , 183. https://doi.org/10.3390/ microorganisms 9010183

Received: 7 January 2021 Accepted: 14 January 2021 Published: 16 January 2021

Publisher's Note: MDPI stays neutral with regard to jurisdictional clai$\mathrm{ms}$ in published maps and institutional affiliations.

Copyright: $\odot 2021$ by the authors. Licensee MDPI, Basel, Switzerland. This article is an open access article distributed under the terms and conditions of the Creative Commons Attribution (CC BY) license (https:// creativecommons.org/licenses/by/ $4.0 /)$.

\begin{abstract}
Streptococcus canis is a common colonizing bacterium of the urogenital tract of cats and dogs that can also cause invasive disease in these animal populations and in humans. Although the virulence mechanisms of $S$. canis are not well-characterized, an M-like protein, SCM, has recently identified been as a potential virulence factor. SCM is a surface-associated protein that binds to host plasminogen and IgGs suggesting its possible importance in host-pathogen interactions. In this study, we developed in vitro and ex vivo blood component models and murine models of $S$. canis vaginal colonization, systemic infection, and dermal infection to compare the virulence potential of the zoonotic S. canis vaginal isolate G361 and its isogenic SCM-deficient mutant (G361 $\Delta s c m)$. We found that while $S$. canis establishes vaginal colonization and causes invasive disease in vivo, the contribution of the SCM protein to virulence phenotypes in these models is modest. We conclude that SCM is dispensable for invasive disease in murine models and for resistance to human blood components ex vivo, but may contribute to mucosal persistence, highlighting a potential contribution to the recently appreciated genetic diversity of SCM across strains and hosts.
\end{abstract}

Keywords: Streptococcus canis; M protein; virulence factor; innate immunity; vaginal colonization

\section{Introduction}

Streptococcus canis is a Gram-positive beta-hemolytic group G Streptococcus that colonizes the epithelial, respiratory, gastrointestinal, and urogenital surfaces of cats and dogs [1-3]. Officially named a species in 1986, S. canis is well-recognized in veterinary medicine for causing a variety of invasive diseases across domestic animal species including sepsis, necrotizing fasciitis, urinary tract infection, ulcerative keratitis, and mastitis [4-9]. Similar S. canis colonization and disease manifestations have been reported in wild animal populations [10-12]. Since its first description as a zoonotic agent in 1996 [13], human cases of S. canis-mediated endocarditis, septicemia, cellulitis, and periprosthetic joint infection have been reported [14-21]. A retrospective study identified S. canis as the causative agent in $\sim 1 \%$ of human streptococcal infections, however, given the reliance of Lancefield classification for group G Streptococcus identification without further speciation, coupled with close interactions between humans and companion animals, it is likely that $S$. canis human infections are underestimated [22,23].

The genetic diversity and molecular pathogenesis of $S$. canis is being actively explored. There are currently more than 50 multi-locus sequence types (MLST) and 20 genomes for S. canis $[23,24]$. The host immune response to $S$. canis is not well-described, yet the pyogenic nature of many S. canis soft tissue infections suggest neutrophils and macrophages may 
be involved. To date, knowledge of $S$. canis virulence factors remains limited, and is largely extrapolated from genetic similarities to the widely-studied group A Streptococcus (S. pyogenes) [12]. Similar to S. pyogenes, S. canis possesses an arginine deiminase system [25], a streptolysin O orthologue [26], lysogenic bacteriophage [27], and an M-like protein termed SCM (or SPASc) [28], which is currently the best characterized among candidate S. canis virulence factors [29].

In S. pyogenes, the M protein, which is genetically diverse with more than $200 \mathrm{emm}$ types, serves multiple roles in pathogenesis and immune evasion [30]. Likewise, S. canis SCM displays genetic heterogeneity. There are currently 15 SCM types divided into group I and II alleles [23]. SCM is a fibrillar surface protein [26] which binds plasminogen [29] and the Fc region of IgGs from multiple species including human, dog, cat, and mouse [31]. We recently demonstrated that SCM self-interactions facilitate bacterial aggregation and that SCM interactions with IgG initiate formation of protein complexes in human plasma [32]. However, the contribution of SCM, and impact of its allelic variability, to S. canis colonization and virulence remains undefined.

In this study, we incorporated in vitro and ex vivo human blood component models, together with murine models of $S$. canis vaginal colonization, systemic infection, and dermal infection to broadly characterize the virulence potential of the zoonotic $S$. canis vaginal isolate G361, originally isolated from a 40-year-old female, and its isogenic SCM-deficient mutant $(\mathrm{G} 361 \Delta s c m)$.

\section{Materials and Methods}

\subsection{Bacterial Strains, Growth Conditions, and In Vitro Phenotyping Assays}

Bacterial strains used in this study include Streptococcus canis human vaginal wildtype (WT) isolate G361 [33] and isogenic scm-targeted insertional mutant G361 $\Delta \mathrm{scm}$ [32], Streptococcus pyogenes human invasive isolate $5448 \mathrm{M} 1$ and isogenic $\Delta e m m 1$ [34], and Streptococcus agalactiae human meningeal isolate $\mathrm{COH} 1$ (ATCC BAA-1176). All bacterial strains were grown to stationary phase in Todd-Hewitt broth (THB, Hardy Diagnostics), or THB agar plates, at $37{ }^{\circ} \mathrm{C}$ without shaking. Erythromycin $(5 \mu \mathrm{g} / \mathrm{mL})$ was added to G361 $\Delta s c m$ to retain the plasmid insertion. Cultures were diluted in fresh THB and incubated at $37^{\circ} \mathrm{C}$ until mid-logarithmic phase (defined as $\mathrm{OD}_{600}=0.4$ ). For growth curves, stationary cultures were diluted to $\mathrm{OD}_{600}=0.1$ in either fresh THB or RPMI-1640 (Gibco) and incubated at $37^{\circ} \mathrm{C}$ for $3 \mathrm{~h}$ with optical density measured every $30 \mathrm{~min}$. To assess hemolytic activity, WT G361 and G361 $\Delta s c m$ were grown overnight and $10 \mu \mathrm{L}$ was spotted onto blood agar plates (TSA with $5 \%$ sheep blood, Thermo Scientific) and incubated for $24 \mathrm{~h}$ at $37^{\circ} \mathrm{C}$ with $5 \% \mathrm{CO}_{2}$. For minimum inhibitory concentrations (MIC), mid-log phase $S$. canis was diluted 1:100 in THB and $100 \mu \mathrm{L}$ was added to 96 -well microtiter plates. Hydrogen peroxide or hypochlorite (1.5-fold dilution series, final concentrations tested $0-3.5 \mathrm{mM}$ and $0-0.34 \mathrm{mM}$ respectively) was diluted in THB and $100 \mu \mathrm{L}$ was added to the bacterial plates $\left(200 \mu \mathrm{L}\right.$ total). The plates were then incubated at $37^{\circ} \mathrm{C}$ for $18 \mathrm{~h}$ and $\mathrm{OD}_{600}$ was measured to determine MIC values (calculated as $90 \%$ reduction in $\mathrm{OD}_{600}$ from S. canis only controls).

\subsection{Biofilm Formation}

S. canis and S. pyogenes biofilms were assessed using methods adapted from previous work [35]. Briefly, stationary cultures were diluted in THB or RPMI- 1640 to $\mathrm{OD}_{600}=0.1$, and $200 \mu \mathrm{L}$ added to tissue culture-treated 96-well plates. Biofilms were allowed to form for $48 \mathrm{~h}$ at $37^{\circ} \mathrm{C}$ without shaking. After washing $3 \mathrm{X}$ with PBS, biofilms were stained with $1 \mu \mathrm{M}$ SYTO 13 nucleic acid stain (Invitrogen) for $30 \mathrm{~min}$ in the dark. Biofilms were then washed $3 \mathrm{X}$ with PBS and quantified by measuring fluorescence at $\mathrm{OD}_{485} / \mathrm{OD}_{520}$ on an Infinite 200 Pro (Tecan) plate reader. Fluorescent images of biofilms were also collected using an Echo Revolve microscope at 100X magnification. 


\subsection{Mammalian Cell Lines and Growth Conditions}

Canine macrophage-like cells (DH82), immortalized human vaginal epithelial cells (VK2/E6E7), and human monocyte cell line (THP-1) were acquired from the American Type Culture Collection (ATCC CRL-10389, ATCC CRL-2616, and ATCC TIB-202 respectively). HEK-Blue IL-1 $\beta$ cells (Cat\# hkb-il1b) were purchased from InvivoGen. DH82 cells were cultured in Eagle's Minimum Essential Medium (EMEM) (Gibco) + 15\% FBS (heat inactivated). VK2 cells were cultured in keratinocyte serum-free medium (KSFM) (Gibco) with $0.5 \mathrm{ng} / \mathrm{mL}$ human recombinant epidermal growth factor and $0.05 \mathrm{mg} / \mathrm{mL}$ bovine pituitary extract. THP- 1 cells were grown in suspension in the following media: RPMI-1640 (Gibco) + 10\% FBS (heat inactivated) $+10 \mathrm{mM}$ HEPES $+1 \mathrm{mM}$ sodium pyruvate $+4500 \mathrm{mg} / \mathrm{L}$ glucose $+1500 \mu \mathrm{g} / \mathrm{mL}$ sodium bicarbonate $+0.05 \mathrm{mM}$ 2-mercaptoethanol. When macrophage differentiation was necessary, the cells were treated for $24 \mathrm{~h}$ with $25 \mathrm{nM}$ phorbol myristate acetate (PMA) to produce an adherent culture. HEK-Blue IL- $1 \beta$ cells were grown in adherent culture in Dulbecco's Modified Eagle Medium (DMEM) with L-glutamine (Gibco) $+10 \%$ FBS (heat inactivated) $+200 \mu \mathrm{g} / \mathrm{mL}$ HygromycinB (InvivoGen) $+100 \mu \mathrm{g} / \mathrm{mL}$ Zeocin (Invitrogen). All cells were cultured in a $37^{\circ} \mathrm{C}$ incubator with $5 \% \mathrm{CO}_{2}$. Adherent cells were split every $3-4$ days at $\sim 80 \%$ confluency, and $0.25 \%$ trypsin $/ 2.21 \mathrm{mM}$ EDTA (Corning) were used to detach DH82 and VK2 cells for passaging. HEK-Blue IL-1 $\beta$ indicator cells were detached with calcium- and magnesium-free sterile PBS.

\subsection{Human Blood Collection and Neutrophil Purification}

Under approval from UC San Diego and Cedars-Sinai Medical Center Institutional Review Boards (Protocol \# 131002), venous blood was obtained after informed consent from healthy adult volunteers, with heparin as an anticoagulant for whole blood and neutrophil studies. Neutrophils were isolated as described previously [36] using PolymorphPrep (Axis-Shield) to create a density gradient by centrifugation according to the manufacturer's instructions.

\subsection{Bacterial Killing Assays}

Bacterial killing assays were modified from previous work [35-37]. For DH82 and THP-1 killing assays, cells were plated in 96-well plates at $3 \times 10^{4}$ cells per well. THP-1 cells were differentiated to macrophages, as described above. The following day S. canis was diluted in PBS and added to the macrophages at multiplicity of infection (MOI) $=1$. The culture plates were centrifuged for $5 \mathrm{~min}$ at $300 \times g$ to facilitate bacterial contact, and then plates were incubated at $30 \mathrm{~min}$ at $37^{\circ} \mathrm{C}$ in $5 \% \mathrm{CO}_{2}$. At the end of incubation, the supernatant was removed, and the macrophages were rinsed once with PBS before being lysed with water, serially diluted, and plated on THB agar. For human neutrophil killing assays, neutrophils were diluted to $2 \times 10^{6}$ cells $/ \mathrm{mL}$ in RPMI-1640 and seeded at $2 \times 10^{5}$ cells/well in 96-well tissue culture plates. S. canis was diluted in RPMI-1640 was added to neutrophils at $\mathrm{MOI}=1$. Plates were centrifuged at $300 \times \mathrm{g}$ for $5 \mathrm{~min}$ to facilitate bacterial contact with neutrophils, and then incubated at $37{ }^{\circ} \mathrm{C}$ in $5 \% \mathrm{CO}_{2}$ for $30 \mathrm{~min}$ or $60 \mathrm{~min}$. Samples were lysed with water, serially diluted, and then plated on THB agar. For human and murine whole-blood killing assays, $90 \mu \mathrm{L}$ of whole blood (peripheral blood from human venipuncture or murine cardiac puncture) and $10 \mu \mathrm{L}$ containing $1 \times 10^{5}$ colonyforming units (CFU) of $S$. canis were incubated at $37^{\circ} \mathrm{C}$ with rotation for $30 \mathrm{~min}$ or $60 \mathrm{~min}$, and plated on THB agar. In all assays, S. canis survival was calculated as a percentage of the inoculum.

\subsection{Reactive Oxygen Species Assays}

Induction of reactive oxygen species release from DH82 cells was adapted from previous work [37]. Briefly, DH82 cells in confluent adherent culture were dissociated and washed in calcium and magnesium-free HBSS. The cells were stained with $2^{\prime}, 7^{\prime}$ dichlorofluorescein diacetate (Sigma Aldrich), seeded into 96-well culture plates, and infected with $S$. canis at MOI $=10$ suspended in HBSS with calcium and magnesium. Plates 
were incubated at $37^{\circ} \mathrm{C}$ with $5 \% \mathrm{CO}_{2}$ for $120 \mathrm{~min}$, and every $20 \mathrm{~min}$, fluorescence intensity (485 nm excitation/530 nm emission) was measured using an EnSpire Multimode Plate Reader (PerkinElmer). Samples were normalized to fold change of fluorescence signal of time $=0$.

\subsection{IL-1 $\beta$ Induction Assays}

Detection of THP-1 cell IL-1 $\beta$ release was measured as adapted from prior work [38]. HEK-Blue IL-1 $\beta$ reporter cells (50,000 cells per well in 96-well plates) were stimulated for $16 \mathrm{~h}$ at $37^{\circ} \mathrm{C}$ in $5 \% \mathrm{CO}_{2}$ with $50 \mu \mathrm{L}$ of supernatants from THP-1 macrophages previously infected with $S$. canis or S. pyogenes at MOI = 1 for $30 \mathrm{~min}$. After $18 \mathrm{~h}$, supernatants from the HEK-Blue cells were analyzed for secreted alkaline phosphatase activity by the addition of $50 \mu \mathrm{L}$ of HEK-Blue supernatants onto $150 \mu \mathrm{L}$ of Quanti-Blue reagent (Invivogen) and monitoring the optical density at $620 \mathrm{~nm}$ via an EnSpire Multimode Plate Reader. Four independent replicate experiments were performed, and data compiled and expressed as relative units normalized to the mean optical density for the GAS group across all four experiments.

\subsection{Adherence Assays}

Vaginal epithelial adherence assays were performed as adapted from prior methods $[35,39]$. VK2 cells were grown to confluency in 24 -well tissue culture plates. Once confluent, VK2 cells were infected with $S$. canis or S. agalactiae at MOI =1 (assuming $1 \times 10^{6}$ VK2 cells per well). Bacteria was brought into contact with the VK2 cells by centrifugation for $1 \mathrm{~min}$ at $300 \times \mathrm{g}$. Cells were incubated at $37^{\circ} \mathrm{C}$ in $5 \% \mathrm{CO}_{2}$ for $30 \mathrm{~min}$, supernatant was removed, and cells washed 6X with sterile PBS. Cell layers were incubated for 5 min with $100 \mu \mathrm{L} 0.25 \%$ trypsin/2.21mM EDTA after which $400 \mu \mathrm{L}$ of $0.025 \%$ Triton-X in PBS was added. Wells were mixed vigorously $30 \mathrm{X}$ to ensure detachment and lysis, and bacterial recovery was determined by plating on THB agar. Data was expressed as a percentage of adherent CFU compared to original inoculum.

\subsection{Human Sera Titer Assays}

For detection of human titers against SCM, a purified truncated form of SCM (KO173225) [31] which does not bind human IgG Fc, was immobilized on 96-well high-binding microtiter plates (Corning Cat\# 3361) at $1 \mu \mathrm{g} /$ well via overnight incubation at RT. Wells were washed $3 X$ with PBS $+0.05 \%$ Tween 20 and blocked with $1 X$ Reagent Diluent (from R\&D Systems, Cat\#841380) for $1 \mathrm{~h}$ at RT. Twenty human serum samples were diluted 1:100, 1:1000, and 1:10,000 in Reagent and added at $100 \mathrm{uL} /$ well. As a positive control, recombinant human IgG (BioRad Cat\# HCA192) was added at $0.5 \mathrm{ug}, 5 \mathrm{ng}$, and $50 \mathrm{pg} /$ well in place of SCM protein. Negative controls included SCM-coated wells incubated with Reagent Diluent. Diluted serum and controls were incubated for $2 \mathrm{~h}$ at $37^{\circ} \mathrm{C}$ and washed $3 \mathrm{X}$ with PBS $+0.05 \%$ Tween 20. Human serum binding was detected using a Goat anti-human Ig AF488 (diluted to 1:500, Southern Biotech, Cat\#2010-30) and incubated for $1 \mathrm{~h}$ at $37^{\circ} \mathrm{C}$ in the dark. Wells were washed $1 \mathrm{X}$ with PBS $+0.05 \%$ Tween 20 and $1 \mathrm{X}$ with PBS alone to remove residual Tween 20. Fluorescence (485 nm excitation/530 nm emission) was detected an EnSpire Multimode Plate Reader and data expressed at relative fluorescence units.

\subsection{Animals}

The UCSD Institutional Animal Care and Use Committee (Protocol \#S00227M) approved all animal protocols and procedures. Wildtype (WT) CD-1 male and female mice aged 8-10 weeks were purchased from Charles River Laboratories (strain code 022). Groups were assigned randomly and housed at 5 animals per cage in separate cages. Mice were allowed to eat and drink ad libitum. 


\subsection{In Vivo Intradermal Infection Model}

For intradermal infection models adapted from prior work [30], CD1 male and female mice ( $n=20$ /group) were shaved $1 \mathrm{~d}$ prior to infection. On each flank, mice were injected subcutaneously with $100 \mu \mathrm{L}$ of PBS containing either $1 \times 10^{8}$ CFU WT S. canis strain G361 or $\Delta s c m$ mutant. Sides receiving WT or $\Delta s c m$ (left and right) were alternated at random across groups of mice. Lesions were imaged daily for three days and surface area calculated using ImageJ software.

\subsection{In Vivo Sepsis Model}

The UCSD Institutional Animal Care and Use Committee (Protocol \#S00227M) approved the anticipated mortality and study design. For in vivo survival studies, CD-1 male and female mice ( $\mathrm{n}=10$ /group) were intraperitoneally (i.p.) injected with $100 \mu \mathrm{L}$ of PBS containing $5 \times 10^{7} \mathrm{CFU}$ wildtype GAS strain 5448, WT S. canis strain G361 or $\Delta$ scm mutant. Mice were monitored three times daily for mortality. Analgesics were not administered during systemic infection due to potential effects on the study outcome.

\subsection{In Vivo Vaginal Colonization Model}

For vaginal colonization models, CD1 females $(n=18$ /group in single challenge experiments or $\mathrm{n}=20$ in competition experiments) were treated i.p. with $0.5 \mathrm{mg} \beta$-estradiol in $100 \mu \mathrm{L}$ sesame oil $(5 \mathrm{mg} / \mathrm{mL})$ to synchronize estrus as described previously [40]. After $24 \mathrm{~h}$, mice were vaginally inoculated with $1 \times 10^{7}$ CFU WT GBS COH1, WT S. canis strain G361 or $\Delta s c m$ mutant suspended in $10 \mu \mathrm{L}$ of PBS. For WT S. canis strain G361 and $\Delta s c m$ competition experiments, mice were vaginally inoculated with $1 \times 10^{7} \mathrm{CFU}$ each of G361 and $\Delta s c m$ suspended in $10 \mu \mathrm{L}$ of PBS. Colonization was monitored daily by collecting vaginal swabs (Puritan, Cat. \# 25-801 A 50). Bacterial load was determined by serial dilution plating on CHROMagar ${ }^{\mathrm{TM}}$ StrepB base (DRG International Inc) and where necessary, WT G361 and $\Delta s c m$ distinguished by plating on CHROMagar containing erythromycin $(5 \mu \mathrm{g} / \mathrm{mL})$.

\subsection{Flow Cytometry}

Vaginal swab samples obtained during swabbing for bacterial colonization were subjected to flow cytometry as adapted from previous work [36,41]. Vaginal lumen cells were released from vaginal swabs by vortexing for 2-3 s, passed through a $40-\mu \mathrm{m}$-pore-size filter, and pelleted at $500 \times g$ for $5 \mathrm{~min}$. Cells were blocked with 1:200 mouse BD Fc-block (BD Biosciences) for $15 \mathrm{~min}$ on ice in $50 \mu \mathrm{L}$ of PBS containing $1 \mathrm{mM}$ EDTA, $1 \%$ FBS, and $0.1 \%$ sodium azide. Cells were stained for surface markers using the following antibodies at $5 \mu \mathrm{g} / \mathrm{mL}$ for $30 \mathrm{~min}$ on ice: anti-CD11b-fluorescein isothiocyanate (FITC) (clone M1/70, catalog no. 553310; BD Pharmingen), anti-c-kit-phycoerythrin (PE) (clone 2B8, catalog no. 1880-09; Southern Biotech), anti-CD8-PerCP-Cy5.5 (where PerCp is peridinin chlorophyll protein) (clone 53-6.7, catalog no. 100734; Biolegend), anti-F4/80-PE-Cy7 (clone BM8, catalog no. 123114; Biolegend), anti-Ly6G-allophycocyanin (APC) (clone 1A8, catalog no. 127614; BioLegend), anti-MHC-II-APC-Fire750 (clone M5/114.15.2, catalog no. 107652; BioLegend), anti-FceRI-Pacific Blue (clone MAR-1, catalog no. 134313; BioLegend), and anti-CD45-BV510 (clone 30-F11, catalog no. 103138; BioLegend). Samples were washed $3 \mathrm{X}$ in PBS containing $1 \mathrm{mM}$ EDTA, $1 \%$ FBS, and $0.1 \%$ sodium azide. Samples were run on a BD FACSCanto II (BD Biosciences), were gated on unstained cells, and positive signals were determined using single-stain controls. Data were analyzed with FlowJo, version 10.2, software (FlowJo LLC).

\subsection{Tissue Histology}

Whole reproductive tract tissues were collected at day 3 post-inoculation, fixed in 10\% neutral buffered formalin for $24 \mathrm{~h}$, and dehydrated by an ethanol gradient and embedded in paraffin. Tissue sectioning and hematoxylin and eosin (H\&E) staining was performed by the UC San Diego Comparative Phenotyping Core. H\&E-stained slides were examined for 
presence and character of inflammation by an ACVP board-certified veterinary anatomic pathologist. Representative images were captured using a Leica brightfield microscope and color CCD camera.

\subsection{Statistical Analyses}

In vitro and ex vivo experiments were repeated at least three times independently with at least three technical replicates with the exception of human serological studies which were performed in technical duplicate and analyzed twice independently. Mean values from independent experiments were used to represent biological replicates for statistical analyses. In vivo experiments were conducted at least twice independently which each mouse serving as a biological replicate. Experimental data was combined prior to statistical analyses. Data sets were subjected to D'Agostino \& Pearson normality test to determine Gaussian distribution before selecting the appropriate parametric or non-parametric analyses. In instances where experimental numbers (n) were too small to determine normality (Figure 1C, Figure 2A,C-F, Figure 3A,B and Figure 4A-C,E) data were assumed non-parametric. Analyses include parametric test two-way ANOVA with Sidak's multiple comparisons post-test, and non-parametric tests including Kruskal Wallis test with Dunn's multiple comparisons post-test, Friedman test with Dunn's multiple comparisons test, Wilcoxon matched-pairs signed rank test with Spearman rank-order correlation, and Log-rank (Mantel-Cox) test as indicated in figure legends. Statistical analyses were performed using GraphPad Prism, version 8.4.3 (GraphPad Software Inc., La Jolla, CA, USA). $p$ values $<0.05$ were considered statistically significant.
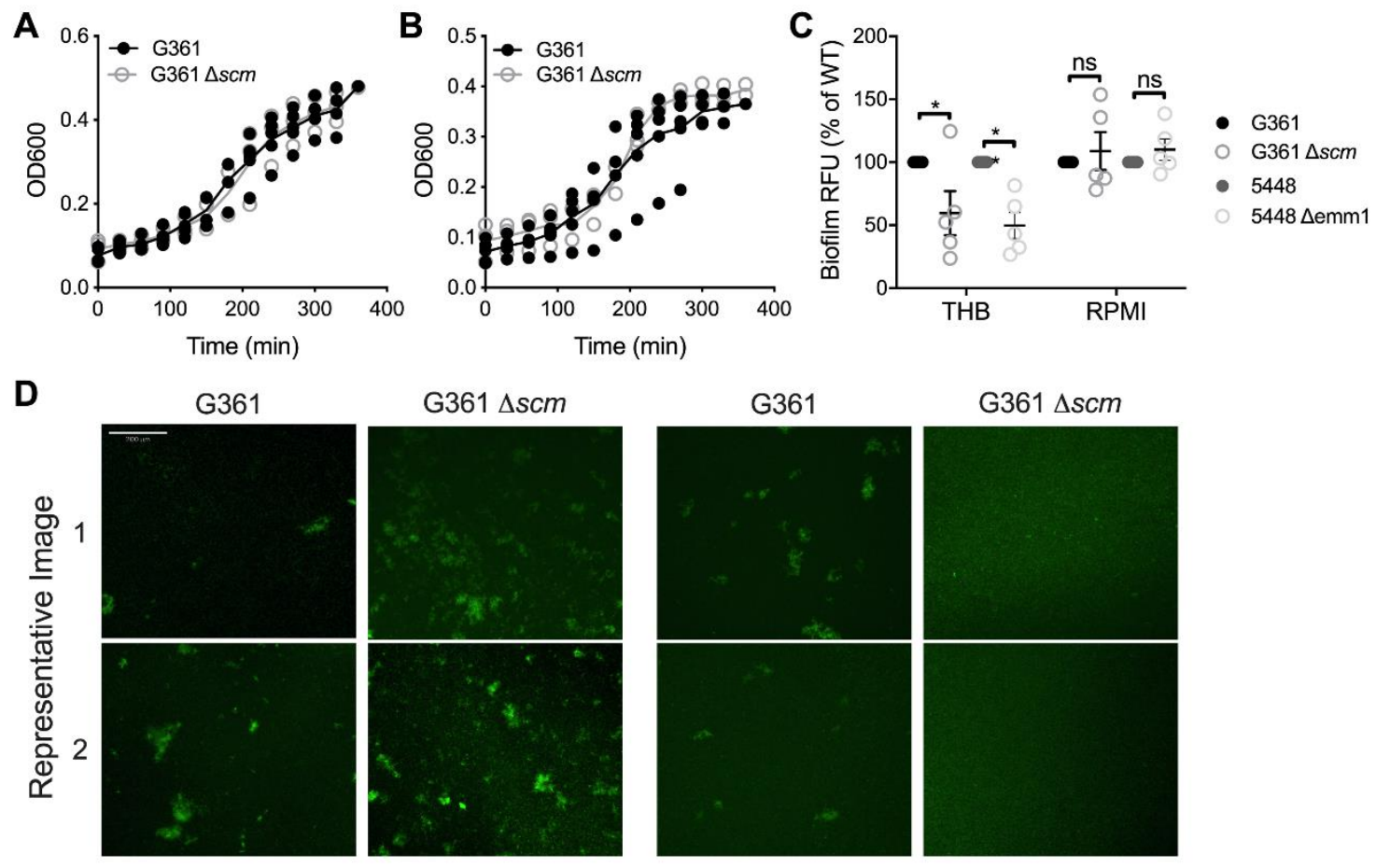

THB

RPMI

Figure 1. SCM deficiency minimally impacts $S$. canis growth, hemolytic activity, and biofilm formation. Growth curves of S. canis G361 or G361 $\Delta$ scm in Todd-Hewitt broth (THB, (A)) or RPMI-1640 (RPMI, (B)) as measured by optical density $\left(\mathrm{OD}_{600}\right)$. (C) Biofilm formation of $S$. canis G361 or G361 $\Delta s c m$ or GAS 5448 or $5448 \Delta e m m 1$ in THB or RPMI quantified by SYTO 13 fluorescence and expressed as the percent fluorescence of the WT strain. (D) Representative images (two per condition) of S. canis G361 or G361 sscm biofilms grown for $48 \mathrm{~h}$ in THB or RPMI and stained with SYTO 13. Symbols represent individual experimental replicates $(\mathbf{A}-\mathbf{C})$ with lines indicating interquartile ranges. Representative images are of independent experimental replicates, scale bar $=200 \mu \mathrm{m}$ (D). Data were analyzed by two-way ANOVA with Sidak's multiple comparisons post-test $(\mathbf{A}-\mathbf{C}){ }^{*}, p<0.05$. 

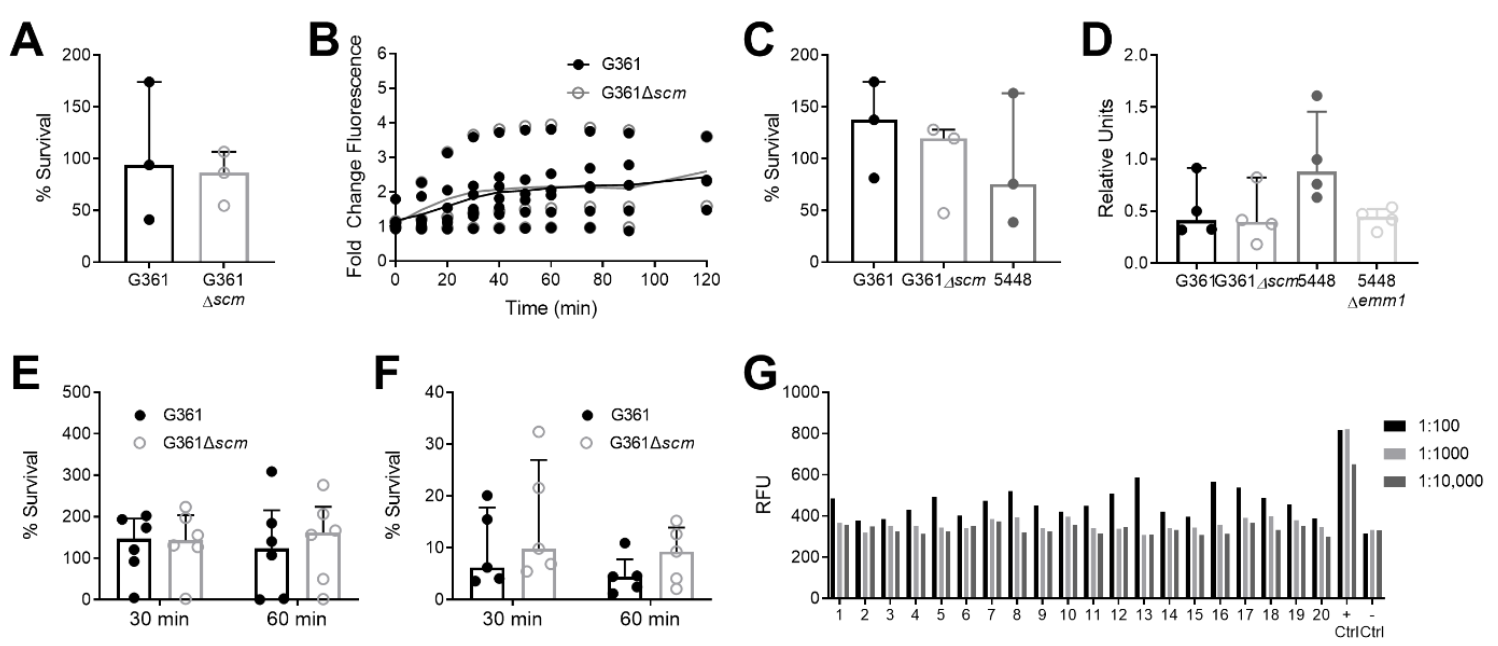

Figure 2. SCM does not alter S. canis survival, reactive oxygen species release, cytokine production, nor induce antigenic activity in human sera. (A) Percent survival of S. canis G361 or G361 sscm after 30 min of exposure to canine DH82 macrophages, $\mathrm{MOI}=1$. (B) Reactive oxygen species production by DH82 macrophages infected with S. canis G361 or $\mathrm{G} 361 \Delta \mathrm{scm}, \mathrm{MOI}=10$, and normalized to uninfected cells. (C) Percent survival of S. canis G361 or G361 $\Delta \mathrm{scm}$ after $30 \mathrm{~min}$ of exposure to human THP-1 differentiated macrophages, MOI = 1. (D) THP-1 cells were infected with $S$. canis G361 or G361 $\Delta s c m, \mathrm{MOI}=1$, and cell supernatant added to HEK-Blue cells. Alkaline phosphatase activity was measured colorimetrically at OD620 and background signal (uninfected cell supernatant) was deducted. Fold IL-1 $\beta$ release was calculated versus GAS across four independent experiments. (E) Percent survival of S. canis G361 or G361 $\Delta s c m$ after 30 or 60 min of infection in human whole blood. (F) Percent survival of S. canis G361 or G361 sscm after 30 or 60 min of infection in isolated human neutrophils, MOI $=1$. (G) Quantification of human IgG titers, expressed as relative fluorescent units (RFU), for a purified truncated form of SCM ( $n=20$ donors) via modified ELISA using diluted human sera, positive control: recombinant human IgG, negative control: buffer only. Symbols represent independent experimental replicates (A-D), biological replicates ((E), $n=6$ /group, $(\mathbf{F}), n=5$ /group), or the results of one independent experiment (G), performed twice independently), with lines indicating medians and interquartile ranges. Data were analyzed by Wilcoxon matched-pairs signed rank test (A), two-way ANOVA with Sidak's multiple comparisons post-test (B,E,F), or Friedman test with Dunn's multiple comparisons test (C,D) and determined not significant.

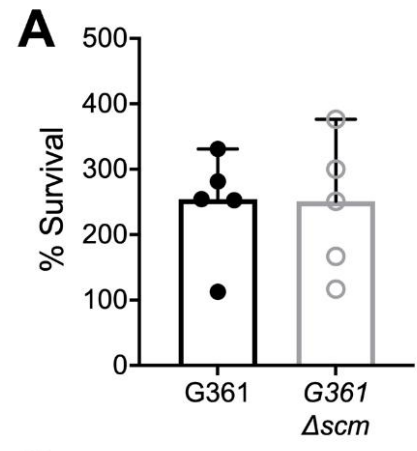

C

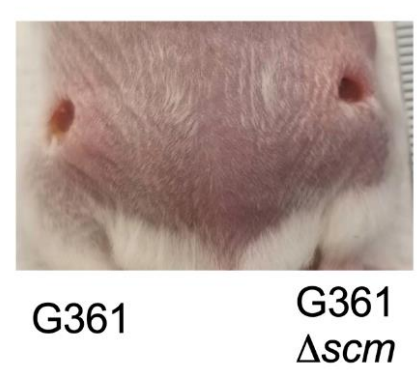

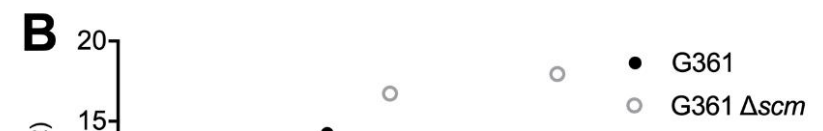

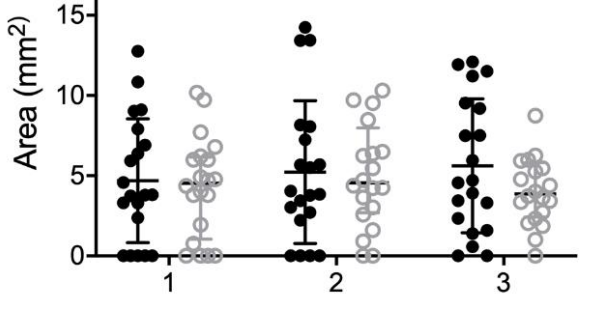

Days Post-Inoculation

D

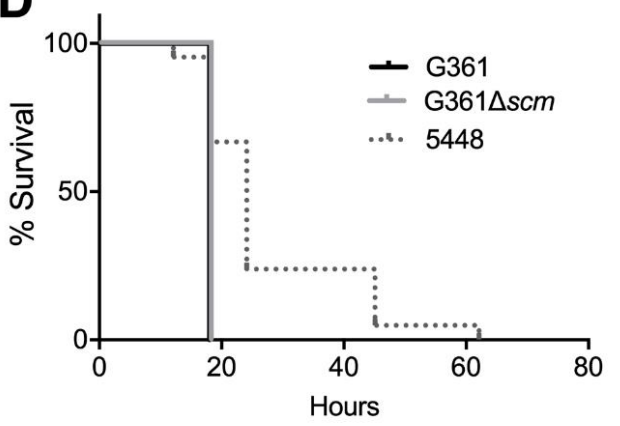

Figure 3. S. canis is highly virulent in mouse models of systemic and dermal infection, yet SCM does not contribute to virulence 
in these models. (A) Percent survival of S. canis G361 or G361 $\mathrm{scm}$ after $30 \mathrm{~min}$ of infection in murine whole blood collected from CD1 mice. (B) CD1 male and female mice were infected subcutaneously with $1 \times 10^{8}$ CFU of WT S. canis G361 or G361 sscm and skin lesion size measured daily. (C) Representative image of skin lesions three days post subcutaneous infection with WT S. canis G361 (left) or G361 $\Delta s c m$ (right). (D) CD1 male and female mice were infected intraperitoneally with $5 \times 10^{7} \mathrm{CFU}$ of WT S. canis G361, G361 $\Delta$ scm, or S. pyogenes 5448 and survival monitored over 3 days. Symbols represent biological replicates ((A), $n=5$ /group, (B), $n=20$ /group, and (D), $n=10-21$ /group) with lines indicating medians and interquartile ranges (A,B) or percentage survival (D). Data were analyzed by Wilcoxon matched-pairs signed rank test (A), two-way ANOVA with Sidak's multiple comparisons post-test (B) or Log rank Mantel-Cox test (D) and determined not significant.
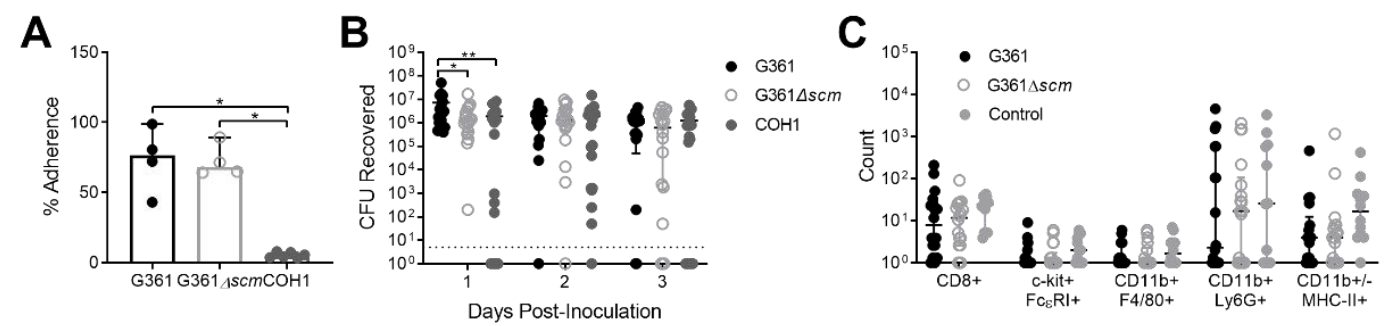

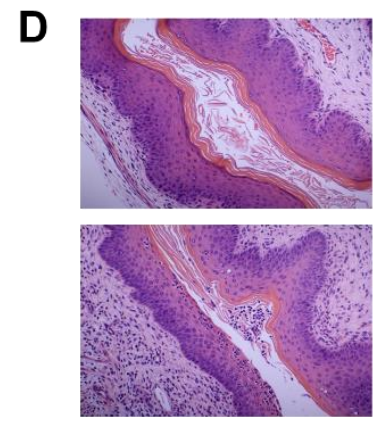

Control
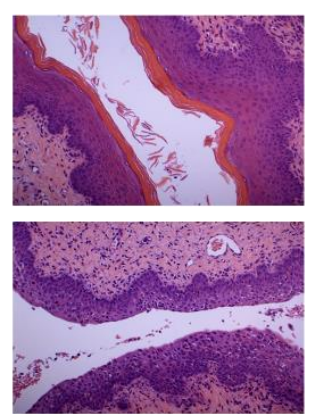

G361

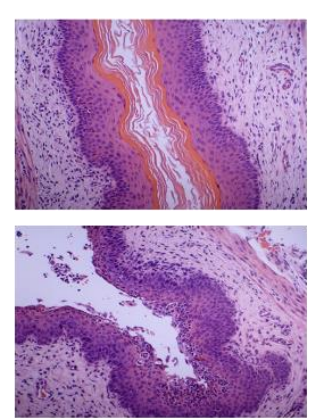

$\mathrm{G} 361 \Delta \mathrm{scm}$
E

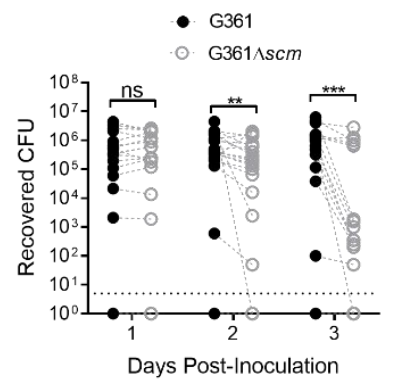

Figure 4. S. canis adheres to vaginal epithelial cells and persists in a murine model of vaginal colonization, and SCM confers a fitness advantage in this environment. (A) Percent adherence of S. canis G361, G361 $s c m$, or GBS COH1 to VK2 cells after $30 \mathrm{~min}$ of infection, $\mathrm{MOI}=1$. CD1 female mice were vaginally administered $1 \times 10^{7} \mathrm{CFU}$ of WT S. canis G361, G361 $\Delta s c m$, or WT GBS COH1, or PBS as a control. (B) Mice were vaginally swabbed daily, and the levels of bacterial CFU recovered from swabs are shown. (C) Cells collected from day 3 post-inoculation were analyzed for surface markers via flow cytometry. Total cell counts of each population recovered on the swabs are shown. (D) Vaginal epithelial tissues were fixed, sectioned, and stained with H\&E. Histological examination revealed keratinized epithelium (top images) and neutrophil infiltration (bottom images) similarly across treatment groups. Magnification $=200 X$. (E) CD1 female mice were vaginally administered $1 \times 10^{7} \mathrm{CFU}$ each of WT S. canis G361 and G361 $\Delta$ scm in competition. Mice were vaginally swabbed daily, and the levels of bacterial CFU recovered from swabs are shown. Symbols represent biological replicates $((\mathbf{B}), n=18 /$ group, (C), $n=12-18$ /group, and (E), $n=20$ /group) or the means of four independent experimental replicates (B), performed in technical duplicate) with lines indicating medians and interquartile ranges. Dotted line in (B,E) indicates limit of detection. Data were analyzed by Kruskal-Wallis test with Dunn's multiple comparisons test (A), two-way ANOVA with Sidak's multiple comparisons post-test $(\mathbf{B}, \mathbf{C})$ or Wilcoxon matched-pairs signed rank test (E). ${ }^{* *}, p<0.001 ;{ }^{* *}, p<0.01 ;{ }^{*}, p<0.05 ; \mathrm{ns,}$ not significant.

\section{Results}

3.1. SCM Deficiency Minimally Impacts S. canis Growth, Biofilm Formation, Hemolytic Activity, and Sensitivity to Aminizing and Oxidizing Agents

The M-protein is a well-characterized virulence factor of S. pyogenes, and the orthologous nature of the SCM protein suggests a potential for a similar role in $S$. canis pathogenesis. To investigate the role of SCM in S. canis virulence, we utilized a SCM insertional mutant made from the $S$. canis G361 clinical isolate strain that no longer produces the SCM protein and exhibits reduced aggregate formation in culture [32]. We confirmed 
that loss of SCM did not alter in vitro growth of S. canis compared to wildtype S. canis in bacteriologic media (THB, Figure 1A) or tissue culture media (RPMI-1640, Figure 1B). Since M protein types have been associated with biofilm formation in S. pyogenes [42], we assessed the contribution of SCM to biofilm formation in S. canis. No differences in biofilm formation between WT G361 and $\Delta s c m$ were observed in RPMI-1640 media, however, in THB media, mutant strains had decreased biofilms relative to WT as detected by fluorescence (Figure 1C). This finding mirrored what was observed in S. pyogenes 5448 and $\Delta e m m 1$. Microscopically, WT G361 formed similar biofilms in THB and RPMI-1640 media, however, $\Delta s c m$ displayed decreased bacterial aggregation in RPMI-1640 compared to WT G361 (Figure 1D). Loss of SCM did not impact beta-hemolytic activity on blood agar (Figure S1). Sensitivity to aminizing or oxidizing agents (hypochlorite and hydrogen peroxide, respectively) was not decreased due to SCM-deficiency (hypochlorite MIC: $0.26 \mathrm{mM}$ and hydrogen peroxide MIC: $0.83 \mathrm{mM}$ for both strains in three independent experiments).

3.2. SCM Does Not Contribute to S. canis Survival, Reactive Oxygen Species Release, or Cytokine Production in Macrophages

The M-protein of S. pyogenes contributes to resistance of host immune cell-mediated killing $[43,44]$. To investigate if the SCM protein of $S$. canis shares these immunomodulatory functions, we conducted bacterial killing and immune response assays in vitro using a variety of immune cell lines as well as whole blood. Using the canine macrophage cell line DH82, we observed no differences in bacterial killing (Figure 2A) or induction of reactive oxygen species (Figure $2 \mathrm{~B}$ ) between $\mathrm{WT}$ and SCM-deficient S. canis. Using the human monocyte cell line THP-1, we observed no differences between differentiated THP-1 cell control of WT and SCM-deficient S. canis, or S. pyogenes WT strain 5448 (Figure 2C). Since S. pyogenes M-protein activates the NLRP3 inflammasome [38], we measured levels of activated IL-1 $\beta$ released by infected THP- 1 cells using an IL-1 $\beta$ HEK-Blue reporter cell assay. Although WT 5448 infection induced twice as much active IL- $1 \beta$ compared to isogenic $\Delta e m m 1$ as observed previously [38], we detected no difference in IL-1 $\beta$ induction between the WT G361 and $\Delta s c m$ conditions, and levels were similar to that induced by the $\Delta e m m 1$ strain (Figure 2D).

\subsection{SCM Deficiency Does Not Alter S. canis Susceptibility to Human Whole Blood and Neutrophils nor Is SCM Antisera Detected in Healthy Human Samples}

To assess $S$. canis virulence in more clinically relevant conditions, we gauged survival of $S$. canis exposed to human whole blood or purified neutrophils isolated from peripheral human blood. We did not detect any differences between WT G361 and $\Delta s c m$ survival in whole blood, and recovered greater than $100 \%$ of the bacterial inoculum in the majority of donors suggesting S. canis is not readily killed in human blood (Figure 2E). Additionally, we did not observe any differences in WT G361 and $\Delta s c m$ exposed to primary human neutrophils (Figure 2F), although bacterial survival across conditions was $<10 \%$, suggesting human neutrophils demonstrate more potent killing than either the canine or human monocyte/macrophage cells lines (Figure 2A,C). The S. pyogenes $\mathrm{M}$ proteins are widely recognized as immunodominant antigens [45], and feline antisera against SCM has been reported [46]. To investigate whether anti-SCM IgG titers are present across healthy human donors, we screened 20 human donors for IgG binding to a purified truncated form of SCM (KO173225) [31] which does not bind human IgG Fc. Human recombinant IgG immobilized on the microtiter plates was used as a positive control. Bound IgG was only detected at 1:100 serum dilutions and did not achieve the level of the positive controls at any dilution, suggesting signal is likely due to background (Figure 2G).

3.4. S. canis Is Highly Virulent in Mouse Models of Systemic and Dermal Infection, yet SCM Does Not Contribute to Virulence in These Models.

Since in vitro assays do not fully reflect complex host-microbe interactions, and thus might not be sensitive enough to assess the subtler contributions of SCM to S. canis virulence, we undertook mouse models of invasive disease. Initial studies with murine whole 
blood revealed no differences between WT G361 and $\Delta s c m$ survival, and we recovered more than $200 \%$ of the bacterial inoculum in the majority of samples suggesting S. canis is not readily killed in mouse blood (Figure 3A). To interrogate whether SCM contributes to S. canis virulence in soft tissue infection, CD1 mice received intradermal injection of $1 \times 10^{8}$ CFU of WT G361 or $\Delta s c m$ and lesion size monitored over 3 days. Although both WT G361 and $\Delta s c m$ led to visible formation of skin lesions, no difference in lesion size was observed at any time point (Figure 3B,C). To assess whether SCM contributes to S. canis morbidity in systemic infection, CD1 mice received intraperitoneal injection with $5 \times 10^{7}$ CFU of WT G361, $\Delta$ scm, or WT S. pyogenes 5448 and mortality monitored over 3 days. Infection with WT G361 or $\Delta s c m$ resulted in rapid decline with $100 \%$ mortality by $18 \mathrm{~h}$ post-infection. In contrast, S. pyogenes 5448 exhibited slower mortality although not statistically significant $(p=0.096$, Figure 3D).

\subsection{S. canis Adheres to Vaginal Epithelial Cells and Persists in a Murine Model of Vaginal Colonization, and SCM Confers a Fitness Advantage in This Environment}

S. canis is commonly isolated from the urogenital tract of dogs [47], and the G361 strain used in these studies was originally isolated on a vaginal swab from a woman who suffered premature membrane rupture during pregnancy [33]. Since the majority of $S$. canis strains are SCM positive [3], we hypothesized that the SCM protein may provide a fitness advantage to $S$. canis in the urogenital tract. To study the potential role of SCM in vaginal colonization, we first assessed the adherence of WT G361 or $\Delta \mathrm{scm}$ to immortalized human vaginal epithelial cells (VK2) and included a strain of the common vaginal colonizing bacterial species group B Streptococcus (GBS) as a comparison. Although no differences in vaginal cell adherence was observed between WT G361 and $\Delta s c m$, both $S$. canis isolates adhered significantly better than GBS ( $p=0.016$ and 0.048 respectively, Figure $4 \mathrm{~A}$ ).

To assess whether SCM contributes to $S$. canis vaginal persistence in vivo, we established a novel mouse model of vaginal colonization using the wildtype and SCM mutant strains of the G361 isolate. Adapted from previous mouse models of GBS vaginal colonization [40], female CD1 mice were synchronized for estrous stage, and inoculated with a single vaginal dose of $1 \times 10^{7} \mathrm{CFU}$ of WT G361, $\Delta \mathrm{scm}$, or GBS, and bacterial burdens monitored via vaginal swabbing daily for 3 days. Mice inoculated with WT G361 exhibited significantly higher bacterial burdens than $\Delta s c m(p=0.013)$ or GBS $(p=0.003)$ on day 1 postinoculation, but no significant differences were seen in subsequent time points (Figure $4 \mathrm{~B}$ ). To determine if $S$. canis induced a local vaginal immune response, cells recovered from day 3 swabs from WT G361, $\Delta s c m$, or PBS-inoculated control mice were stained and analyzed via flow cytometry with antibodies for the following cell surface markers: CD45, CD11b, CD8, major histocompatibility complex class II (MHC-II), F4/80, Ly6G, FceRI, and c-kit. CD45+ cells were analyzed for the presence of additional surface markers and total cell counts of each sub-category were reported. CD8+ T cells (CD45+ CD8+), mast cells (CD45+ c-kit+ FceRI+), macrophages (CD45+ CD11b+ F4/80+), neutrophils (CD11b+ Ly6G+), and antigen presenting cells (CD11b+/- MHC-II+) were all observed, but numbers did not significantly differ across groups (Figure 4C). Additionally, we collected reproductive tract tissues at day 3 post-inoculation. Histological examination of the vaginal epithelium showed a range of appearances consistent with estrus (keratinized epithelium, Figure 4D, top images) or metestrus (neutrophil infiltration, Figure 4D, bottom images), no differences were observed across treatment groups. To determine whether SCM-deficiency confers a disadvantage to $S$. canis vaginal colonization, female CD1 mice were vaginally inoculated with equal amounts of WT G361 and $\Delta s c m\left(1 \times 10^{7}\right.$ CFU of each) and bacterial burdens quantified over 3 days via vaginal swab. WT G361 and $\Delta s c m$ were differentiated by plating on agar with and without erythromycin. In competition, $\Delta s c m$ showed significantly lower burdens than WT G361 on days 2 and 3 post-inoculation. To confirm that the $\Delta s c m$ mutant was not losing the plasmid insertion in vivo over time, we assessed the stability of erythromycin resistance in CD1 mice singly challenged with $\Delta s c m$ by plating on both selective and non-selective agar plates. No differences were observed in bacterial counts using either erythromycin selection or no selection (Figure S2). 


\section{Discussion}

S. canis is a well-known pathogen of dogs, cats, and other mammals, and an opportunistic zoonotic disease of humans [48-52], yet molecular factors promoting colonization and virulence are poorly understood. SCM is hypothesized to have similar roles as the diverse M-like proteins of other streptococcal species in the context of pathogenesis and immune evasion. To this point, multiple studies demonstrate SCM interactions with host proteins [29,31,53]; however, to date, studies have not investigated the role that SCM plays in pathogenesis and colonization in vivo. Our work seeks to bridge this gap in knowledge and define the importance of SCM in epithelial and immune cell interactions in vitro and in novel mouse models of $S$. canis pathogenesis and colonization. Overall, we observed minimal contributions of SCM to S. canis interactions with the host in either commensal or pathogen contexts using the S. canis strain G361 which possesses a SCM type 2, group 1 allele [12]. Importantly, it remains possible that SCM proteins belonging to different group alleles may differentially impact $S$. canis interactions with its host. Prevalence of SCM in veterinary S. canis isolates is quite high: both colonizing and invasive isolates are $70.6-90.0 \%$ SCM positive by PCR $[3,54]$ suggesting possible biological pressure(s) to retain SCM for successful S. canis colonization and/or invasive disease.

In terms of bacterial characteristics, SCM is non-essential for growth, either in nutrientrich bacteriologic media or nutrient-poor tissue culture media. SCM also does not contribute to hemolysis in S. canis, similar to reports for other streptococcal M-like proteins [55]. In S. pyogenes, M1 over-expression enhances biofilm formation and M1-deficient strains demonstrated reduced biofilm formation in bacteriologic media [42]. Similarly, we noted decreased biofilm formation in SCM-deficient S. canis in bacteriologic media, however, this finding was not observed in conditions reflective of the host environment (RPMI, Figure 1C). In S. pyogenes, M protein contributes to the hydrophobicity of the bacterial surface, leading to greater biofilm formation [42]. Thus, loss of SCM in S. canis possibly reduces surface proteins with greater hydrophobicity, leading to the observed decrease in biofilm formation. Alternatively, because SCM activity is associated with S. canis aggregation microcolony formation in vitro [56], loss of homophilic interactions between SCM in the $\Delta s c m$ strain may alter the morphology of S. canis biofilms [32,57]. In fact, although there was no difference in the relative fluorescent units (RFU) of WT G361 and $\Delta s c m$ biofilms in RPMI-1640, the morphology of the biofilms was visibly different. While WT G361 biofilms grown in RPMI-1640 formed microcolonies comparable to WT G361 grown in THB, $\Delta s c m$ grown in RPMI-1640 formed diffuse biofilms with fewer microcolonies (Figure 1D). The impact of this altered biofilm morphology on S. canis interactions within different host tissues is a topic of future study.

Streptococcal $\mathrm{M}$ proteins play key roles in virulence and host immune evasion. S. pyogenes $\mathrm{M}$ proteins confer resistance against phagocytosis by inhibiting the alternate complement pathway [58,59], or alternatively, through forming bacterial aggregates with self $[56,60]$ or as a complex with host cells $[61,62]$. Similarly, in S. canis, this selfaggregation is lost in the absence of SCM [32]. However, in our assays with canine or human macrophage cell lines, we found that presence of SCM did not alter macrophagemediated killing of $S$. canis (Figure 2). In fact, neither WT or $\Delta s \mathrm{~cm}$ bacteria were effectively controlled by macrophage cell lines or human and mouse whole blood, with $\sim 100 \%$ or more of inoculum recovered at the experimental end point. This contrasts our findings with isolated human neutrophils, which efficiently reduced S. canis viability by more than $90 \%$ over the assay (Figure 2F), yet with no significant contribution of SCM to S. canis neutrophil resistance. This observation is in line with a previous study which did not observe any differences in neutrophil control of SCM-positive or SCM-negative S. canis except for when exogenous SCM and/or plasminogen was present [57].

Another notable activity of M-like proteins is resistance to host immune defense molecules and activation of innate inflammatory responses, best characterized in S. pyogenes. S. pyogenes M1 neutralizes cathelicidin [30,34], stimulates neutrophil recruitment and myeloperoxidase release [63], and activates the NLRP3 inflammasome triggering 
IL-1 $\beta$-dependent pyroptosis in macrophages [38]. In our in vitro immune cell models, we observed no differences in reactive oxygen species (ROS) production or induction of IL-1 $\beta$ between SCM-deficient and wildtype S. canis (Figure 2). Overall, we observed only modest induction of ROS, and minimal induction of IL-1 $\beta$ in macrophages infected with S. canis with levels similar to that of M protein-deficient S. pyogenes. This failure to elicit an immune response could benefit $S$. canis as it avoids the production of inflammatory cytokines and pyroptosis that have been shown to be critical for the control of some bacterial pathogens [64]. However, in our in vivo models of $S$. canis invasive infection, we did not distinguish distinctive contributions of SCM. No differences in skin lesion sizes were observed between SCM-deficient and WT S. canis, and in general, we observed smaller lesion sizes than that reported for a similar model in S. pyogenes [30]. Time points beyond 3 days were not assessed in our studies. We observed high lethality of $S$. canis compared to S. pyogenes in a murine model of systemic infection at a dose of $5 \times 10^{7} \mathrm{CFU}$, similar to a previous study, which demonstrated an LD90 of $3 \times 10^{7}$ CFU in mice [28].

Additionally, the antigenic nature of S. pyogenes M proteins is well-recognized [65,66], and anti-M protein responses are associated with host protection against repeat infection by strains of the same M type $[67,68]$. Regarding S. canis, antisera against SCM has been detected in diseased cats [46]. No compelling evidence for SCM anti-sera in healthy human donors was detected in our cohort, however, subjects with known active or prior S. canis infections or exposure were not included in this study.

Along with relevance to pathogenesis, streptococcal $\mathrm{M}$ proteins play prominent roles in host colonization. This phenomenon may be in part due to mediating adherence [69], although M proteins may not necessarily promote adhesion to all epithelial types [56], and expression of certain $\mathrm{M}$ proteins may even reduce epithelial adherence [70]. Although we observed no contribution of SCM in adherence to human vaginal epithelial cells in vitro, it is possible that these cells do not produce the same extracellular matrix or surface proteins to recapitulate in vivo conditions. Furthermore, we observed a striking increase is S. canis adherence to VK2 compared to the frequently isolated vaginal bacterium group B Streptococcus (Figure 3) [71,72] but the underlying molecular basis for this heightened adherence is currently unknown. In vivo, S. canis persisted in the mouse vaginal tract at similar levels to GBS highlighting the utility of this murine model in studying S. canis factors contributing to urogenital colonization. We detected no changes to immune cell profiles or epithelial appearance suggesting that $S$. canis does not stimulate a robust vaginal immune response soon after introduction. This contrasts with other human pathogen vaginal colonization models which do invoke immune responses [72-74] and may reflect the primarily colonizing role for $S$. canis in mammals such as cats and dogs. Although we observed minimal contribution of SCM in S. canis colonization in a single bacterial challenge model, when both WT S. canis and $\Delta \mathrm{scm}$ were introduced in competition, WT S. canis demonstrated a competitive advantage (Figure $4 \mathrm{E}$ ). The underlying mechanisms for this SCM-mediated advantage in niche establishment are unknown, but this finding provides rationale for the conservation and heterogenetic variability of SCM across clinical isolates $[12,23]$.

In summary, we have deployed several new in vitro and mouse models of S. canis infection and colonization and interrogated the role of SCM in these models using a targeted knockout mutant. We observed minimal impact of SCM deficiency in invasive disease models, but found an SCM-associated advantage in vaginal colonization. These results suggest that the role of SCM is distinct from the repertoire of virulence mechanisms ascribed to other streptococcal $\mathrm{M}$ proteins. Further studies are necessary to determine the mechanisms underlying decreased colonization fitness of SCM-deficient S. canis and to extend our findings to other SCM variants. Identification of these mechanisms will provide insight into the viability of SCM as a vaccine target for the zoonotic pathogen S. canis.

Supplementary Materials: The following are available online at https://www.mdpi.com/2076-2 607/9/1/183/s1, Figure S1: SCM has no effect on hemolytic activity; Figure S2: SCM insertional mutagenesis is stable in vivo. 
Author Contributions: Conceptualization, I.C., V.N., K.A.P.; methodology, I.C., J.O., K.A.P.; formal analysis, I.C.; investigation, I.C., K.A.P.; resources, M.F. and V.N.; data curation, I.C., J.Z., K.A.P.; writing-original draft preparation, J.Z., I.C., K.A.P.; writing-review and editing, All authors; visualization, J.Z., I.C., K.A.P.; funding acquisition, V.N. All authors have read and agreed to the published version of the manuscript.

Funding: This research was funded by NIH grant 1 R01 AI154149 to VN. KAP was supported by UC Chancellor's and Hartwell Foundation postdoctoral fellowships and a Research Scholar Award from the American Urological Association.

Institutional Review Board Statement: The study was conducted according to the guidelines of the Declaration of Helsinki, and approved by the Institutional Review Boards of UC San Diego and Cedars-Sinai Medical Center (protocol number 131002, approved 09/20/2018).

Informed Consent Statement: Informed consent was obtained from all subjects involved in the study.

Data Availability Statement: The data presented in this study are available in Supplementary Material Raw Data Files here.

Acknowledgments: We are grateful to Barbara A. Byrne for her helpful discussion and comments on the manuscript. We thank the UC San Diego Comparative Phenotyping Core for technical assistance and the UC San Diego vivarium staff for animal care and management. Additionally, the authors would like to thank George Y. Liu and Juan R. Caldera obtaining and curating human sera samples, and Antje-Maria G. Lapschies for preparation of purified KO173225 protein.

Conflicts of Interest: The authors declare no conflict of interest. The funders had no role in the design of the study; in the collection, analyses, or interpretation of data; in the writing of the manuscript, or in the decision to publish the results.

\section{References}

1. Devriese, L.A.; Cruz Colque, J.I.; De Herdt, P.; Haesebrouck, F. Identification and composition of the tonsillar and anal enterococcal and streptococcal flora of dogs and cats. J. Appl. Bacteriol. 1992, 73, 421-425. [CrossRef] [PubMed]

2. Guerrero, A.E.; Stornelli, M.C.; Jurado, S.B.; Giacoboni, G.; Sguazza, G.H.; de la Sota, R.L.; Stornelli, M.A. Vaginal isolation of beta-haemolytic Streptococcus from bitches with and without neonatal deaths in the litters. Reprod. Domest. Anim. 2018, 53, 609-616. [CrossRef] [PubMed]

3. Verkuhlen, G.; Pagelow, D.; Valentin-Weigand, P.; Fulde, M. SCM-positive Streptococcus canis are predominant among petassociated group G streptococci. Berl. Munch. Tierarztl. Wochenschr. 2016, 129, 247-250. [PubMed]

4. Ulrich, S.; Gottschalk, C.; Straubinger, R.K.; Schwaiger, K.; Dorfelt, R. Acceleration of the identification of sepsis-inducing bacteria in cultures of dog and cat blood. J. Small Anim. Pract. 2020, 61, 42-45. [CrossRef] [PubMed]

5. Costa, R.S.; Costa, F.B.; Barros, R.R. Antimicrobial treatment of necrotizing fasciitis and septic polyarthritis in a cat associated with Streptococcus canis infection. Vet. Dermatol. 2018, 29, 90-91. [CrossRef]

6. Moyaert, H.; Morrissey, I.; de Jong, A.; El Garch, F.; Klein, U.; Ludwig, C.; Thiry, J.; Youala, M. Antimicrobial Susceptibility Monitoring of Bacterial Pathogens Isolated from Urinary Tract Infections in Dogs and Cats Across Europe: ComPath Results. Microb. Drug Resist. 2017, 23, 391-403. [CrossRef]

7. Enache, A.E.; Mitchell, C.; Kafarnik, C.; Waller, A.S. Streptococcus canis multilocus sequence typing in a case series of dogs with ulcerative keratitis. Vet. Ophthalmol. 2020, 23, 252-258. [CrossRef]

8. Krol, J.; Twardon, J.; Mrowiec, J.; Podkowik, M.; Dejneka, G.; Debski, B.; Nowicki, T.; Zalewski, W. Short communication: Streptococcus canis is able to establish a persistent udder infection in a dairy herd. J. Dairy Sci. 2015, 98, 7090-7096. [CrossRef]

9. Pesavento, P.A.; Bannasch, M.J.; Bachmann, R.; Byrne, B.A.; Hurley, K.F. Fatal Streptococcus canis infections in intensively housed shelter cats. Vet. Pathol. 2007, 44, 218-221. [CrossRef]

10. Callealta, I.; Ganswindt, A.; Goncalves, S.; Mathew, A.; Lueders, I. Detection of Simonsiella spp. in the Vagina of Lions and Leopard in Oestrus. Reprod. Domest. Anim. 2018, 53, 1605-1608. [CrossRef]

11. Seguel, M.; Gutierrez, J.; Hernandez, C.; Montalva, F.; Verdugo, C. Respiratory Mites (Orthohalarachne diminuata) and betahemolytic Streptococci-Associated Bronchopneumonia Outbreak in South American Fur Seal Pups (Arctocephalus australis). J. Wildl. Dis. 2018, 54, 380-385. [CrossRef] [PubMed]

12. Pinho, M.D.; Foster, G.; Pomba, C.; Machado, M.P.; Baily, J.L.; Kuiken, T.; Melo-Cristino, J.; Ramirez, M.; Portuguese Group for the Study of Streptococcal, I. Streptococcus canis Are a Single Population Infecting Multiple Animal Hosts Despite the Diversity of the Universally Present M-Like Protein SCM. Front. Microbiol. 2019, 10, 631. [CrossRef] [PubMed]

13. Bert, F.; Lambert-Zechovsky, N. Septicemia caused by Streptococcus canis in a human. J. Clin. Microbiol. 1997, 35, 777-779. [CrossRef] [PubMed]

14. Lacave, G.; Coutard, A.; Troche, G.; Augusto, S.; Pons, S.; Zuber, B.; Laurent, V.; Amara, M.; Couzon, B.; Bedos, J.P.; et al. Endocarditis caused by Streptococcus canis: An emerging zoonosis? Infection 2016, 44, 111-114. [CrossRef] [PubMed] 
15. Cheong, B.M.; Lim, A.Y. Sharing a microbe with man's best friend: A case of canine streptococcal infection in a diabetic patient. Med. J. Malays. 2015, 70, 318-319.

16. Lederman, Z.; Leskes, H.; Brosh-Nissimov, T. One Health and Streptococcus Canis in the Emergency Department: A Case of Cellulitis and Bacteremia in an Immunocompromised Patient Treated With Etanercept. J. Emerg. Med. 2020, 58, e129-e132. [CrossRef]

17. Zaidi, S.M.H.; Eranki, A. Streptococcus canis Bacteremia in a Renal Transplant Recipient. J. Investig. Med. High Impact Case Rep. 2019, 7. [CrossRef]

18. Malisova, B.; Santavy, P.; Loveckova, Y.; Hladky, B.; Kotaskova, I.; Pol, J.; Lonsky, V.; Nemec, P.; Freiberger, T. Human native endocarditis caused by Streptococcus canis-a case report. APMIS 2019, 127, 41-44. [CrossRef]

19. Taniyama, D.; Abe, Y.; Sakai, T.; Kikuchi, T.; Takahashi, T. Human case of bacteremia caused by Streptococcus canis sequence type 9 harboring the scm gene. IDCases 2017, 7, 48-52. [CrossRef]

20. Amsallem, M.; Iung, B.; Bouleti, C.; Armand-Lefevre, L.; Eme, A.L.; Touati, A.; Kirsch, M.; Duval, X.; Vahanian, A. First reported human case of native mitral infective endocarditis caused by Streptococcus canis. Can. J. Cardiol. 2014, 30, 1462.e1-2. [CrossRef]

21. Tarabichi, M.; Alvand, A.; Shohat, N.; Goswami, K.; Parvizi, J. Diagnosis of Streptococcus canis periprosthetic joint infection: The utility of next-generation sequencing. Arthroplast. Today 2018, 4, 20-23. [CrossRef] [PubMed]

22. Galperine, T.; Cazorla, C.; Blanchard, E.; Boineau, F.; Ragnaud, J.M.; Neau, D. Streptococcus canis infections in humans: Retrospective study of 54 patients. J. Infect. 2007, 55, 23-26. [CrossRef] [PubMed]

23. Fukushima, Y.; Takahashi, T.; Goto, M.; Yoshida, H.; Tsuyuki, Y. Novel diverse sequences of the Streptococcus canis M-like protein (SCM) gene and their prevalence in diseased companion animals: Association of their alleles with sequence types. J. Infect. Chemother. 2020, 26, 908-915. [CrossRef] [PubMed]

24. National Center for Biotechnology Information. Streptococcus Canis. Available online: https://www.ncbi.nlm.nih.gov/genome/ ?term $=$ streptococcus+canis (accessed on 9 October 2020).

25. Hitzmann, A.; Bergmann, S.; Rohde, M.; Chhatwal, G.S.; Fulde, M. Identification and characterization of the arginine deiminase system of Streptococcus canis. Vet. Microbiol. 2013, 162, 270-277. [CrossRef] [PubMed]

26. DeWinter, L.M.; Low, D.E.; Prescott, J.F. Virulence of Streptococcus canis from canine streptococcal toxic shock syndrome and necrotizing fasciitis. Vet. Microbiol. 1999, 70, 95-110. [CrossRef]

27. Ingrey, K.T.; Ren, J.; Prescott, J.F. A fluoroquinolone induces a novel mitogen-encoding bacteriophage in Streptococcus canis. Infect. Immun. 2003, 71, 3028-3033. [CrossRef]

28. Yang, J.; Liu, Y.; Xu, J.; Li, B. Characterization of a new protective antigen of Streptococcus canis. Vet. Res. Commun. 2010, 34, 413-421. [CrossRef]

29. Fulde, M.; Rohde, M.; Hitzmann, A.; Preissner, K.T.; Nitsche-Schmitz, D.P.; Nerlich, A.; Chhatwal, G.S.; Bergmann, S. SCM, a novel M-like protein from Streptococcus canis, binds (mini)-plasminogen with high affinity and facilitates bacterial transmigration. Biochem. J. 2011, 434, 523-535. [CrossRef]

30. LaRock, C.N.; Dohrmann, S.; Todd, J.; Corriden, R.; Olson, J.; Johannssen, T.; Lepenies, B.; Gallo, R.L.; Ghosh, P.; Nizet, V. Group A Streptococcal M1 Protein Sequesters Cathelicidin to Evade Innate Immune Killing. Cell Host Microbe 2015, 18, 471-477. [CrossRef]

31. Bergmann, S.; Eichhorn, I.; Kohler, T.P.; Hammerschmidt, S.; Goldmann, O.; Rohde, M.; Fulde, M. SCM, the M Protein of Streptococcus canis Binds Immunoglobulin G. Front. Cell. Infect. Microbiol. 2017, 7, 80. [CrossRef]

32. Nerlich, A.; Lapschies, A.M.; Kohler, T.P.; Cornax, I.; Eichhorn, I.; Goldmann, O.; Krienke, P.; Bergmann, S.; Nizet, V.; Hammerschmidt, S.; et al. Homophilic protein interactions facilitate bacterial aggregation and IgG-dependent complex formation by the Streptococcus canis M protein SCM. Virulence 2019, 10, 194-206. [CrossRef] [PubMed]

33. Eichhorn, I.; van der Linden, M.; Jarek, M.; Fulde, M. Draft Genome Sequence of Zoonotic Streptococcus canis Isolate G361. Genome Announc. 2017, 5. [CrossRef] [PubMed]

34. Lauth, X.; von Kockritz-Blickwede, M.; McNamara, C.W.; Myskowski, S.; Zinkernagel, A.S.; Beall, B.; Ghosh, P.; Gallo, R.L.; Nizet, V. M1 protein allows Group A streptococcal survival in phagocyte extracellular traps through cathelicidin inhibition. J. Innate Immun. 2009, 1, 202-214. [CrossRef] [PubMed]

35. Patras, K.A.; Derieux, J.; Al-Bassam, M.M.; Adiletta, N.; Vrbanac, A.; Lapek, J.D.; Zengler, K.; Gonzalez, D.J.; Nizet, V. Group B Streptococcus Biofilm Regulatory Protein A Contributes to Bacterial Physiology and Innate Immune Resistance. J. Infect. Dis. 2018, 218, 1641-1652. [CrossRef] [PubMed]

36. Patras, K.A.; Ha, A.D.; Rooholfada, E.; Olson, J.; Ramachandra Rao, S.P.; Lin, A.E.; Nizet, V. Augmentation of Urinary Lactoferrin Enhances Host Innate Immune Clearance of Uropathogenic Escherichia coli. J. Innate Immun. 2019, 11, 481-495. [CrossRef] [PubMed]

37. Patras, K.A.; Coady, A.; Olson, J.; Ali, S.R.; RamachandraRao, S.P.; Kumar, S.; Varki, A.; Nizet, V. Tamm-Horsfall glycoprotein engages human Siglec-9 to modulate neutrophil activation in the urinary tract. Immunol. Cell Biol. 2017, 95, 960-965. [CrossRef] [PubMed]

38. Valderrama, J.A.; Riestra, A.M.; Gao, N.J.; LaRock, C.N.; Gupta, N.; Ali, S.R.; Hoffman, H.M.; Ghosh, P.; Nizet, V. Group A streptococcal M protein activates the NLRP3 inflammasome. Nat. Microbiol. 2017, 2, 1425-1434. [CrossRef]

39. Patras, K.A.; Wescombe, P.A.; Rosler, B.; Hale, J.D.; Tagg, J.R.; Doran, K.S. Streptococcus salivarius K12 Limits Group B Streptococcus Vaginal Colonization. Infect. Immun. 2015, 83, 3438-3444. [CrossRef]

40. Patras, K.A.; Doran, K.S. A Murine Model of Group B Streptococcus Vaginal Colonization. J. Vis. Exp. 2016. [CrossRef] 
41. Patras, K.A.; Coady, A.; Babu, P.; Shing, S.R.; Ha, A.D.; Rooholfada, E.; Brandt, S.L.; Geriak, M.; Gallo, R.L.; Nizet, V. Host Cathelicidin Exacerbates Group B Streptococcus Urinary Tract Infection. mSphere 2020, 5. [CrossRef]

42. Courtney, H.S.; Ofek, I.; Penfound, T.; Nizet, V.; Pence, M.A.; Kreikemeyer, B.; Podbielski, A.; Hasty, D.L.; Dale, J.B. Relationship between expression of the family of $\mathrm{M}$ proteins and lipoteichoic acid to hydrophobicity and biofilm formation in Streptococcus pyogenes. PLoS ONE 2009, 4, e4166. [CrossRef]

43. Cole, J.N.; Pence, M.A.; von Kockritz-Blickwede, M.; Hollands, A.; Gallo, R.L.; Walker, M.J.; Nizet, V. M protein and hyaluronic acid capsule are essential for in vivo selection of covRS mutations characteristic of invasive serotype M1T1 group A Streptococcus. mBio 2010, 1. [CrossRef] [PubMed]

44. Henningham, A.; Dohrmann, S.; Nizet, V.; Cole, J.N. Mechanisms of group A Streptococcus resistance to reactive oxygen species FEMS Microbiol. Rev. 2015, 39, 488-508. [CrossRef] [PubMed]

45. Dale, J.B.; Smeesters, P.R.; Courtney, H.S.; Penfound, T.A.; Hohn, C.M.; Smith, J.C.; Baudry, J.Y. Structure-based design of broadly protective group a streptococcal M protein-based vaccines. Vaccine 2017, 35, 19-26. [CrossRef]

46. Timoney, J.F.; Velineni, S.; Ulrich, B.; Blanchard, P. Biotypes and ScM types of isolates of Streptococcus canis from diseased and healthy cats. Vet. Rec. 2017, 180, 358. [CrossRef]

47. Biberstein, E.L.; Brown, C.; Smith, T. Serogroups and biotypes among beta-hemolytic streptococci of canine origin. J. Clin. Microbiol. 1980, 11, 558-561. [CrossRef]

48. Miller, C.W.; Prescott, J.F.; Mathews, K.A.; Betschel, S.D.; Yager, J.A.; Guru, V.; DeWinter, L.; Low, D.E. Streptococcal toxic shock syndrome in dogs. J. Am. Vet. Med. Assoc. 1996, 209, 1421-1426.

49. Iglauer, F.; Kunstyr, I.; Morstedt, R.; Farouq, H.; Wullenweber, M.; Damsch, S. Streptococcus canis arthritis in a cat breeding colony. J. Exp. Anim. Sci. 1991, 34, 59-65.

50. Hassan, A.A.; Akineden, O.; Usleber, E. Identification of Streptococcus canis isolated from milk of dairy cows with subclinical mastitis. J. Clin. Microbiol. 2005, 43, 1234-1238. [CrossRef]

51. Whatmore, A.M.; Engler, K.H.; Gudmundsdottir, G.; Efstratiou, A. Identification of isolates of Streptococcus canis infecting humans. J. Clin. Microbiol. 2001, 39, 4196-4199. [CrossRef]

52. Lam, M.M.; Clarridge, J.E., 3rd; Young, E.J.; Mizuki, S. The other group G Streptococcus: Increased detection of Streptococcus canis ulcer infections in dog owners. J. Clin. Microbiol. 2007, 45, 2327-2329. [CrossRef] [PubMed]

53. Lammler, C.; Frede, C.; Gurturk, K.; Hildebrand, A.; Blobel, H. Binding activity of Streptococcus canis for albumin and other plasma proteins. J Gen. Microbiol. 1988, 134, 2317-2323. [CrossRef] [PubMed]

54. Fukushima, Y.; Yoshida, H.; Goto, M.; Tsuyuki, Y.; Takahashi, T. Prevalence and diversity of M-like protein (SCM) gene in Streptococcus canis isolates from diseased companion animals in Japan: Implication of SCM allele. Vet. Microbiol. 2018, 225, 120-124. [CrossRef] [PubMed]

55. Locke, J.B.; Aziz, R.K.; Vicknair, M.R.; Nizet, V.; Buchanan, J.T. Streptococcus iniae M-like protein contributes to virulence in fish and is a target for live attenuated vaccine development. PLOS ONE 2008, 3, e2824. [CrossRef]

56. Caparon, M.G.; Stephens, D.S.; Olsen, A.; Scott, J.R. Role of M protein in adherence of group A streptococci. Infect. Immun. 1991, 59, 1811-1817. [CrossRef]

57. Fulde, M.; Rohde, M.; Polok, A.; Preissner, K.T.; Chhatwal, G.S.; Bergmann, S. Cooperative plasminogen recruitment to the surface of Streptococcus canis via M protein and enolase enhances bacterial survival. mBio 2013, 4, e00629-12. [CrossRef]

58. Fischetti, V.A.; Gotschlich, E.C.; Siviglia, G.; Zabriskie, J.B. Streptococcal M protein: An antiphagocytic molecule assembled on the cell wall. J. Infect. Dis. 1977, 136 (Suppl. 1), S222-S233. [CrossRef]

59. Fischetti, V.A. Streptococcal M protein: Molecular design and biological behavior. Clin. Microbiol. Rev. 1989, 2, 285-314. [CrossRef]

60. Frick, I.M.; Morgelin, M.; Bjorck, L. Virulent aggregates of Streptococcus pyogenes are generated by homophilic protein-protein interactions. Mol. Microbiol. 2000, 37, 1232-1247. [CrossRef]

61. Beachey, E.H.; Stollerman, G.H. Toxic effects of streptococcal M protein on platelets and polymorphonuclear leukocytes in human blood. J. Exp. Med. 1971, 134, 351-365. [CrossRef]

62. Hurley, S.M.; Kahn, F.; Nordenfelt, P.; Morgelin, M.; Sorensen, O.E.; Shannon, O. Platelet-Dependent Neutrophil Function Is Dysregulated by M Protein from Streptococcus pyogenes. Infect. Immun. 2015, 83, 3515-3525. [CrossRef] [PubMed]

63. Soehnlein, O.; Oehmcke, S.; Ma, X.; Rothfuchs, A.G.; Frithiof, R.; van Rooijen, N.; Morgelin, M.; Herwald, H.; Lindbom, L. Neutrophil degranulation mediates severe lung damage triggered by streptococcal M1 protein. Eur. Respir. J. 2008, 32, $405-412$. [CrossRef]

64. Franchi, L.; Munoz-Planillo, R.; Nunez, G. Sensing and reacting to microbes through the inflammasomes. Nat. Immunol. 2012, 13, 325-332. [CrossRef] [PubMed]

65. Lancefield, R.C. Persistence of type-specific antibodies in man following infection with group A streptococci. J. Exp. Med. 1959, 110, 271-292. [CrossRef] [PubMed]

66. Fox, E.N. M proteins of group A streptococci. Bacteriol. Rev. 1974, 38, 57-86. [CrossRef] [PubMed]

67. Courtney, H.S.; Hasty, D.L.; Dale, J.B. Serum opacity factor (SOF) of Streptococcus pyogenes evokes antibodies that opsonize homologous and heterologous SOF-positive serotypes of group A streptococci. Infect. Immun. 2003, 71, 5097-5103. [CrossRef]

68. Mills, J.S.; Jayashi, C.M.F.; Reynolds, S.; Wun, C.; Calcutt, A.; Baker, S.B.; Murugappan, S.; Depelsenaire, A.C.I.; Dooley, J.; Fahey, P.V.; et al. M-protein based vaccine induces immunogenicity and protection from Streptococcus pyogenes when delivered on a high-density microarray patch (HD-MAP). NPJ Vaccines 2020, 5, 74. [CrossRef] 
69. Schrager, H.M.; Alberti, S.; Cywes, C.; Dougherty, G.J.; Wessels, M.R. Hyaluronic acid capsule modulates M protein-mediated adherence and acts as a ligand for attachment of group A Streptococcus to CD44 on human keratinocytes. J. Clin. Investig. 1998, 101, 1708-1716. [CrossRef]

70. Anderson, E.L.; Cole, J.N.; Olson, J.; Ryba, B.; Ghosh, P.; Nizet, V. The fibrinogen-binding M1 protein reduces pharyngeal cell adherence and colonization phenotypes of M1T1 group A Streptococcus. J. Biol. Chem. 2014, 289, 3539-3546. [CrossRef]

71. Patras, K.A.; Wang, N.Y.; Fletcher, E.M.; Cavaco, C.K.; Jimenez, A.; Garg, M.; Fierer, J.; Sheen, T.R.; Rajagopal, L.; Doran, K.S. Group B Streptococcus CovR regulation modulates host immune signalling pathways to promote vaginal colonization. Cell Microbiol. 2013, 15, 1154-1167. [CrossRef]

72. Patras, K.A.; Rosler, B.; Thoman, M.L.; Doran, K.S. Characterization of host immunity during persistent vaginal colonization by Group B Streptococcus. Mucosal Immunol. 2015, 8, 1339-1348. [CrossRef] [PubMed]

73. Sierra, L.J.; Brown, A.G.; Barila, G.O.; Anton, L.; Barnum, C.E.; Shetye, S.S.; Soslowsky, L.J.; Elovitz, M.A. Colonization of the cervicovaginal space with Gardnerella vaginalis leads to local inflammation and cervical remodeling in pregnant mice. PLoS ONE 2018, 13, e0191524. [CrossRef] [PubMed]

74. Carey, A.J.; Weinberg, J.B.; Dawid, S.R.; Venturini, C.; Lam, A.K.; Nizet, V.; Caparon, M.G.; Walker, M.J.; Watson, M.E.; Ulett, G.C. Interleukin-17A Contributes to the Control of Streptococcus pyogenes Colonization and Inflammation of the Female Genital Tract. Sci. Rep. 2016, 6, 26836. [CrossRef] [PubMed] 